\title{
A RETROSPECTIVE STUDY ON CLINICAL AND EPIDEMIOLOGICAL PROFILE AMONGST POST OPERATED PATIENTS OF CHRONIC SUPPURATIVE OTITIS MEDIA (CSOM) AT A TERTIARY CARE CENTER.
}

\author{
Authors: Harendra Kumar Gautam (1), S.K. Kanuajia (2), Astha Singh (3), NS Saxena (4), Amrita \\ Srivastava* (5), Saumya KumarTiwari (6).
}

Author's Affiliation: (1) Associate Professor (2) Professor \& Head (3, 5) Senior Resident $(4,6)$ Assistant Professor, Department of ENT, GSVM Medical College, Kanpur, U.P. 208002

\section{Abstract}

Background: Chronic suppurative otitis media (CSOM) remains one of the most common ear diseases in the general population. The socioeconomic burden of CSOM is still very high both financially and non-financially for the society. There is a need for capacity building to reduce the burden as well as the associated risk. Aims and Objectives: The aim of this study was to study the clinical and epidemiological profile of post operated patients of chronic suppurative otitis media (CSOM) at a tertiary care center. Materials and Methods: This was a retrospective study of 265 patients of clinically diagnosed CSOM. The study was carried out at the ENT department, LLR hospital, GSVM medical college Kanpur during the period of 6 years from August 2013 to July 2019. Results: The data collected from the Clinicoepidemiological study of chronic suppurative otitis media carried out on 265 patients, showed that 197 patients had unilateral ear disease while 68 patients had bilateral ear disease. Among 265 patients, 126 (47.54\%) were male and 139 (52.42\%) were female. $44.15 \%$ patients were in age group 11 to 20 years of age. $72.82 \%$ patients belonged to lower socioeconomic status. Tubotympanic type constituted majority 207 (78.12\%) cases followed by atticoantral type in 58 (21.88\%) cases. Most patients presented with moderate hearing impairment 113 (42.64\%). Conclusion: CSOM is a preventable cause of hearing impairment. Early diagnosis and management can effectively reduce the socioeconomic burden and prevent deafness.

Keywords: CSOM, Socioeconomic status, Hearing impairment.

\section{Introduction}

Chronic suppurative otitis media (CSOM) remains one of the most common ear diseases having a prevalence of $5.2 \%$ in the general population. [1] Chronic otitis media (COM) equates with the term chronic "suppurative" otitis media that is no longer advocated, as COM is not necessarily a result of "the gathering of pus." However, the distinction remains between active COM, where there is inflammation and the production of pus, and inactive COM, where there is no inflammation and the production of pus. [2] Incidence of this disease is the higher in developing countries, because of malnutrition, overcrowding, poor hygiene, inadequate health care, and recurrent upper respiratory tract infection.[3] In the developing countries, there is differential prevalence among the different socioeconomic strata of the community.[4] The socioeconomic cost of CSOM is still very high both financially and non-financially for the society. There is a need for capacity building to reduce the burden as well as the associated risk. [5] It is the commonest childhood infectious disease worldwide [6] starting early in life, but in our environment, presentation may be in adult life. [7] CSOM is usually classified into two types: Tubotympanic and atticoantral depending on whether disease process affects 
pars tensa or pars flaccid of the tympanic membrane. [8].

The aims of managing the chronic discharging ear are early detection and timely, appropriate intervention to eradicate the disease permanently or to reduce its effects (i.e., ear discharge, hearing loss, and other complications) if eradication is not possible. [9]

\section{Material and Method}

This was a retrospective study of 265 patients of clinically diagnosed CSOM. The study was carried out in the Department of ENT of a tertiary-care Medical College and Hospital during the period of 6 years from August 2013 to July 2019.The relevant data were collected with regard to age and sex distribution, type of CSOM, laterality, type of discharge, associated complaints, duration between incidence and presentation, clinical presentation, radiological findings, management, and complications. Xray mastoid bilateral Schuller's view, HRCT Temporal bone and Culture and Sensitivity of discharge were carried out in selected cases.

\section{Results}

The data collected from the Clinicoepidemiological study of chronic suppurative otitis media carried out on 265 patients, revealed that 197 patients had unilateral ear disease while 68 patients had bilateral ear disease. The data were analyzed statistically and following observations were made. Among 265 patients, 126 (47.54\%) were male and $139(52.42 \%)$ were female. $44.15 \%$ patients were in age group 11 to20 years.[Tab-1]

Table 1: Distribution of patients according to age and gender.

\begin{tabular}{|l|l|l|l|}
\hline Age group (years) & Male & Female & Total \\
\hline $11-20$ & 56 & 61 & 117 \\
\hline $21-30$ & 33 & 34 & 67 \\
\hline $31-40$ & 24 & 38 & 62 \\
\hline $41-50$ & 10 & 4 & 14 \\
\hline $51-60$ & 3 & 2 & 5 \\
\hline Total & 126 & 139 & 265 \\
\hline
\end{tabular}

Figure 1: Distribution of patients according to age and gender.

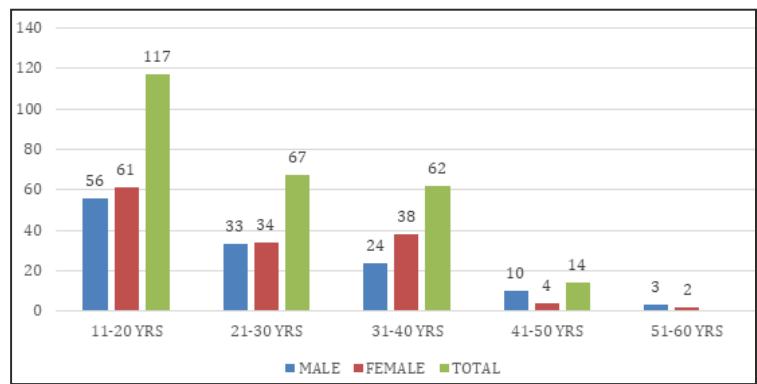

$72.82 \%$ patients belonged to lower socioeconomic status. [Tab-2]

Tab-2 Distribution of patients according to socioeconomic status.

\begin{tabular}{|l|l|}
\hline Socioeconomic condition patients & No. of Patients (\%) \\
\hline Upper & $12(4.52 \%)$ \\
\hline Upper middle & $20(7.54 \%)$ \\
\hline Lower middle & $40(15.09 \%)$ \\
\hline Upper lower & $83(31.32 \%)$ \\
\hline Lower & $110(41.50 \%)$ \\
\hline Total & $265(100 \%)$ \\
\hline
\end{tabular}

Figure 2: Distribution of patients according to socioeconomic status.

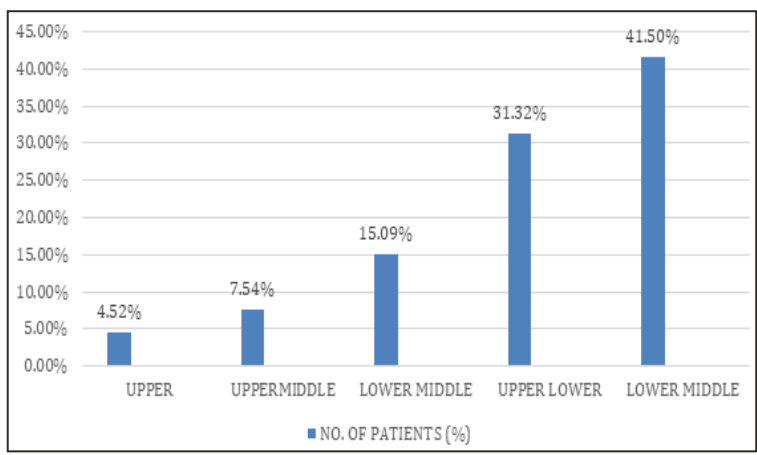

DISTRIBUTION OF PATIENTS ACCORDING TO SOCIOECONOMICTubotympanic type constituting majority $207(78.12 \%)$ cases trailed by atticoantral type $58(21.88 \%)$ cases.[Tab-3]

Table 3: Distribution of Patients according to type of CSOM.

\begin{tabular}{|l|l|}
\hline Type of CSOM & No. of Patients (\%) \\
\hline Tubotympainc type & $207(78.12 \%)$ \\
\hline Atticoantral type & $58(21.88 \%)$ \\
\hline Total & $265(100 \%)$ \\
\hline
\end{tabular}


Figure 3: Distribution of Patients according to type of CSOM.

DISTRIBUTION OF PATIENTS ACCORDING TO TYPE OF CSOM

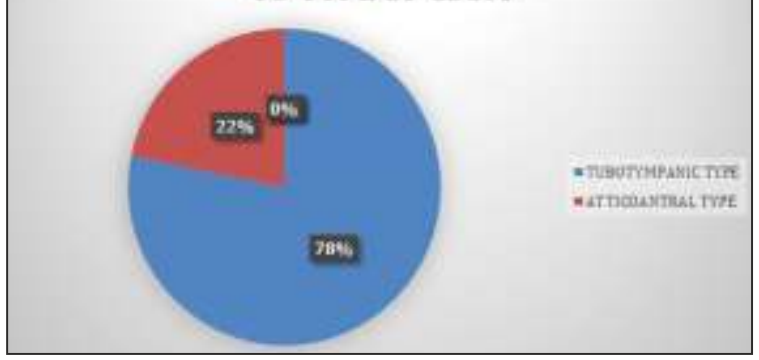

Most patients presented with moderate hearing impairment 113 (42.64\%), while mild hearing impairment was seen in 89 cases (33.58\%).[Tab-4]

Table-4: Distribution of patients according to hearing loss.

\begin{tabular}{|l|l|}
\hline Degree of Hearing Loss & No. of Patients (\%) \\
\hline Mild & $89(33.58 \%)$ \\
\hline Moderate & $113(42.64 \%)$ \\
\hline Severe & $47(17.73 \%)$ \\
\hline Profound & $16(6.03 \%)$ \\
\hline Total & $265(100 \%)$ \\
\hline
\end{tabular}

Figure 4: Distribution of patients according to hearing loss.

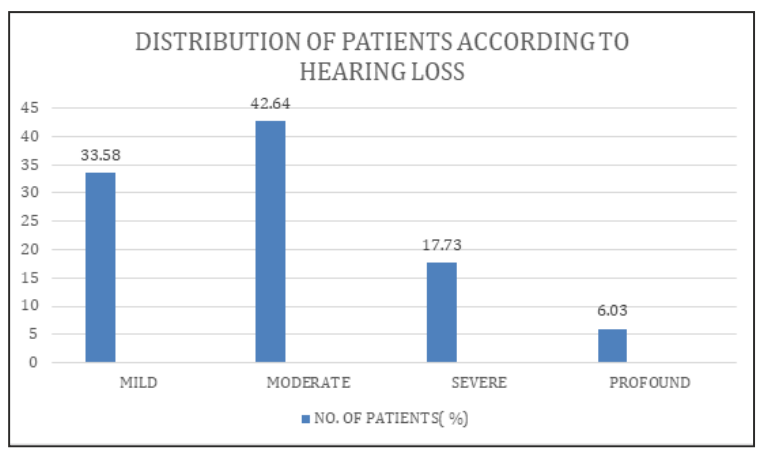

\section{Discussion}

Out of total 265 patients $44.15 \%$ were in age group of 11 to 20 years. Findings of this study is similar to study carried out by Gupta and Mittal, where majority of patients were of the age group of $10-20$ years. ${ }^{[10]}$
In our study $72.82 \%$ patients belonged to lower socioeconomic status, which was similar to Gupta and Mittal ${ }^{[10]}$ study where most patients belonged to poor socioeconomic status (SES class IV, V comprised more than three-fourth of patients). This may be attributed to unhealthy living conditions, unbalanced diet, and poor hygiene and the economic strains of the patients with regard to seeking health services.

Analysis of the gender distribution in this study revealed that CSOM was found to be more common in females 139 (52.42\%) than in males 126 (47.54\%). Consistent results were obtained by Sharma A et al ${ }^{[11]}$ and Nazir and Kadri, ${ }^{[12]}$ while a study by Patigaroo et al. ${ }^{[13]}$ and Moshi et al. ${ }^{[14]}$ showed a higher incidence in male population as compared to females.

In present study Tubotympanic type comprised majority 201 (75.84\%) cases followed by atticoantral type 58 (21.88\%) cases. Findings of this study are similar to study carried out by Kabdwal $\mathrm{N}$ et al. where out of a total of 80 patients, $61(76.25 \%)$ were of safe CSOM whereas 19 (23.75\%) were unsafe CSOM. ${ }^{[15]}$

In the study conducted by Aditya Singhal et al, most patients presented with moderate hearing impairment (43.75\%) and mild hearing impairment (31.25\%). ${ }^{[16]}$ This is similar to our study where most patients presented with moderate hearing impairment 113 (42.64\%), followed by mild hearing impairment 89 (33.58\%).

\section{Conclusion}

CSOM is a preventable cause of hearing impairment. Early diagnosis and management can effectively reduce the socioeconomic burden and prevent deafness. It is an infection commonly associated with poor socioeconomic status related conditions such as malnutrition, overcrowding, poor hygiene and recurrent URTI. 


\section{Reference}

1. World Health Organization. State of hearing and ear care in the South East Asia Region. WHO Regional Office for South East Asia. WHOSEARO. SEA/Deaf/9. Available at:http://www.searo.who.int/LinkFil es/Publications_HEARING_\&_EAR_ CARE.pdf. Accessed on 10 January 2010.

2. Browning GG, Kelly G, Swan IR, Canter R, McKerrow SW. In: Gleeson MJ, Bruton MJ, editors. ScottBrown's Otorhinolaryngology Head and Neck. London: Edward Arnold; 2008.

3. Kumar $\mathrm{H}$, Seth $\mathrm{S}$. Bacterial and fungal study of 100 cases of chronic suppurative otitis media. J Clin Diagn Res. 2011;5:1224-7.

4. Adhikari P, Joshi S, Kharel B. Chronic suppurative otitis media in urban private school children of Nepal. Braz J Otorhinolaryngol. 2009; 75(5):669-72.

5. Afolabi OA, Fadare JO, Omokanye HK, Olatoke F, Odi TO, Saka MJ, et al. Socioeconomic challenges of chronic suppurative otitis media management in state tertiary health facility in Nigeria. Egypt J Ear Nose Throat Allied Sci. 2014; 15(1):17-22.

6. Verhoeff $M$, van der Veen EL, Rovers MM, Sanders EA, Schilder AG. Chronic suppurative otitis media: a review. Int J Pediatr Otorhinolaryngol 2006; 70(1):1-12.

7. Okafor BC. The chronic discharging ear in Nigeria. J Laryngol Otol1984; 98(2):113-9.

8. Kumar H., Seth S. Bacterial and fungal study of 100 cases of chronic suppurative otitis media. J Clin Diag Res 2011;5:1224-7.

9. Acuin JM. Chronic suppurative otitis media: a disease waiting for solutions. Comm Ear Hearing $\mathrm{H}$ 2007;4(6):17-19.

10. Gupta R, Mittal M. A study on clinical and epidemiological profile of chronic suppurative otitis media (CSOM) at a tertiary care center. Int J Med Sci Public Health. 2016; 5(5):1021-4.

11. Sharma A, Banerjee $M$, Mehra M, Khandelwal P, Taneja V. Bacteriology and antibiotic sensitivity of chronic suppurative otitis media in a government hospital. Indian J Otol 2018; 24:214-8.

12. Asifa Nazir, S. M. Kadri. Aerobic bacteriology of chronic suppurative otitis media: a hospital based study. Int J Res Med Sci. 2014 Nov; 2(4):1521-1525.

13. Patigaroo SA, Wani SM, Anjum N, Islam $M$, Sumbrai $D$, Ahmad R. Drift in the bacteriology of chronic suppurative otitis media and methicillin-resistant Staphylococcus aureus as an 
emerging pathogen: an experience. Int J Med Sci Public Health 2016; 5:671-

14. Moshi NH, Minja BM, Ole-Lengine L, Mwakagile DS. Bacteriology of chronic otitis media in Dar es Salaam, Tanzania. East Afr Med J 2000; 77:20-2.

15. Kabdwal N, Varshney S, Bist SS, Bhagat S, Mishra S, Agarwal V. Pre and post-operative evaluation of hearing in chronic suppurative otitis media. Indian J Otol 2013; 19:164-8.

16. Aditya Singhal, Pooja Agrawal, Vijender Kumar Agrawal. Prevalence and determinants of chronic suppurative otitis media in school going children in Bareilly ( Uttar Pradesh). Int J Otorhinolaryngol Head Neck Surg. 2018Mar; 4(2):348-351.

\section{*Corresponding Author}

Dr. Amrita Srivastava

Assistant Professor

Department of ENT

GSVM Medical College

Kanpur 